\title{
PERFORMANCE OF DIFFERENT ORGANIC MANURES WITH CHEMICAL FERTILIZERS IN INCREASING GROWTH, YIELD AND NUTRITIONAL QUALITY OF POTATO (SOLANUM TUBEROSUM L.)
}

\author{
Md Rafiqul Islam*, Tahsina Sharmin Hoque, Sadia Islam, \\ Mohiuddin Ahmed ${ }^{1}$ and Md Mozammel Hoque ${ }^{2}$ \\ Department of Soil Science, Bangladesh Agricultural University, \\ Mymensingh-2202, Bangladesh
}

Keywords: Kazi compost, Organic manures, Potato, Yield, Nutrient uptake

\begin{abstract}
Influence of various organic manures with chemical fertilizers on increasing growth, yield and nutritional quality of potato was studied. The experiment consisted of seven treatments including $\mathrm{T}_{0}$ : Control, $\mathrm{T}_{1}: 75 \%$ recommended fertilizer dose (RFD); $\mathrm{T}_{2}: 100 \%$ RFD, $\mathrm{T}_{3}: 75 \% \mathrm{RFD}+$ Kazi compost (5 t/ha), $\mathrm{T}_{4}: 75 \%$ RFD + Kazi compost ( $3 \mathrm{t} / \mathrm{ha}), \mathrm{T}_{5}: 75 \% \mathrm{RFD}+$ Poultry manure ( $\left.3 \mathrm{t} / \mathrm{ha}\right)$ and $\mathrm{T}_{6}: 75 \% \mathrm{RFD}+$ Cowdung (5 t/ha). Among the organic manures, Kazi compost performed the best which compensated up to $25 \%$ of recommended inorganic fertilizers and significantly improved the growth components, yield parameters, tuber yield and nutrient uptake by potato. In field performance, Kazi compost @ 5 t/ha was effective followed by poultry manure and can be recommended for better growth, yield and nutritional quality of potato.
\end{abstract}

\section{Introduction}

Potato (Solanum tuberosum L.), a non-grain tuber crop under Solanaceae is grown in more than 125 countries and consumed daily by more than a billion people of the world (Sanwen Huang et al. 2011). It is the fourth most important food crop in the world after rice, wheat and maize in terms of human consumption (Kandil et al. 2011, Devaux et al. 2014). Potato is an alternative to grain crop contributing to the global food requirement and is considered as a world leading vegetable crop along with the cheapest source of carbohydrate, protein, fat, vitamins (A, B and C), minerals and antioxidants with a high biological value (Hale et al. 2008). In Bangladesh, potato is a famous vegetable which is either consumed directly or processed to make products such as chips, French fries, mashed and canned potatoes etc. With increasing population, Bangladesh is facing the challenges of ensuring food and nutritional security. Considering the trend of population growth and consequently the increased demand for food in the country and dwindling cultivable land area, potato is likely to play a pivotal role in the future. Value addition of potato contributes to crop diversification, improves farmers' income and provides value export with additional employment (Hussain 2016). However, at present nearly 476 thousand hectares of cultivable land is under potato cultivation and the country produced 9725 thousand $\mathrm{m}$ tons of potato in the year 2017-2018 (SYB 2018). The average yield of potato in Bangladesh is quite low in comparison to that in other potato producing countries like France, the Netherlands and the USA (Siddique et al. 2015).

Fertilizer is one of the most important inputs of increasing crop production and its application has immense effects on crop quality. Potato is highly responsive to nutrient fertilization and to achieve high yield, a reasonable amount of nutrients should be present in the soil. The improper

*Author for correspondence: <rafiqss69@bau.edu.bd>. ${ }^{1}$ Soil Resource Development Institute, Farmgate, Dhaka-1215, Bangladesh. ${ }^{2}$ Department of Food Engineering \& Tea Technology, Shahjalal University of Science \& Technology, Sylhet 3114, Bangladesh. 
use of chemical fertilizers can potentially disturb the natural functioning of soil and affect the output of other ecosystem services (Timsina 2018). The improper use of chemical fertilizers with little or no addition of organic manures has caused many detrimental effects in agriculture including soil fertility depletion, nutrient mining, organic matter decline etc. Organic manures such as poultry manure, cowdung, cattle manure, compost etc. are environment friendly, easily available and their application on agricultural land can increase microbial activity, improve soil fertility as well as crop yield and thus, now-a-days the use of organic manures has been widely accepted for sustainable agriculture. In the last few decades, many research works have been conducted that suggest the use of organic manures to be indispensable for potato cultivation to increase the growth and tuber yield. Thus this work was undertaken to compare the effects of various kinds of organic manures in association with chemical fertilizers on growth, yield and nutritional quality of potato in two different locations.

\section{Materials and Methods}

Two separate locations were selected for performing the study viz. Soil Science Field laboratory of Bangladesh Agricultural University (BAU), Mymensingh and a farmer's field at Sutiakhali village of Mymensingh Sadar during the rabi season of 2018-2019. For both sites, the soils belong to the Sonatala series of AEZ 9 (Old Brahmaputra Floodplain). The soil of BAU farm was silt loam in texture having $\mathrm{pH} 6.5$, organic matter content $1.8 \%$, total nitrogen $(\mathrm{N}) 0.1 \%$, available phosphorus (P) $4.2 \mathrm{ppm}$, exchangeable potassium (K) $0.1 \mathrm{me} \%$ and available sulphur (S) $13.3 \mathrm{ppm}$. On the contrary, the soil of farmer's field was loam in texture having $\mathrm{pH} 6.3$, organic matter content $1.9 \%$, total $\mathrm{N} 0.2 \%$, available P 3.7 ppm, exchangeable K $0.2 \mathrm{me} \%$ and available $\mathrm{S}$ $11.3 \mathrm{ppm}$. The experiment was laid out in a Randomized Complete Block Design (RCBD) with three replications for each site. The treatments were $\mathrm{T}_{0}$ (Control), $\mathrm{T}_{1}$ (75\% RFD), $\mathrm{T}_{2}(100 \% \mathrm{RFD})$, $\mathrm{T}_{3}(75 \% \mathrm{RFD}+$ Kazi compost $5 \mathrm{t} / \mathrm{ha}), \mathrm{T}_{4}(75 \% \mathrm{RFD}+$ Kazi compost $3 \mathrm{t} / \mathrm{ha}), \mathrm{T}_{5}(75 \% \mathrm{RFD}+$ Poultry manure $3 \mathrm{t} / \mathrm{ha}$ ) and $\mathrm{T}_{6}(75 \% \mathrm{RFD}+$ Cowdung $5 \mathrm{t} / \mathrm{ha})$. For each location, the experimental area was divided into three blocks representing the replications and each block was subdivided into seven-unit plots where the treatments were randomly distributed. The total number of plots was $3 \times 7=21$ and the size of the unit plot was $4 \mathrm{~m} \times 3 \mathrm{~m}$. Potato (cv. Diamant) was used as test crop whose seeds (cut tubers) were sown in pits at $2.5 \mathrm{~cm}$ soil depth following furrow method. Pit to pit distance was $25 \mathrm{~cm}$ and row to row distance was $60 \mathrm{~cm}$. Some intercultural operations like earthing up, irrigation, weeding and pesticide application were performed as and when necessary. The recommended doses of N, P, K, S, zinc (Zn) and boron (B) were 135, 30, 90, 10, 1.5 and $1.5 \mathrm{~kg} / \mathrm{ha}$, respectively (FRG 2018) which were supplied from urea, triple super phosphate (TSP), muriate of potash (MoP), gypsum, zinc oxide and boric acid, respectively.

All the organic manures and the full doses of TSP, gypsum, zinc oxide and boric acid as well as half doses of urea and MoP were applied as basal during final land preparation. The remaining half doses of urea and MoP were applied as side dressing at 30 days after earthing up. The tuber crop was harvested on full maturity and the data on growth and yield components were recorded. Tuber samples were collected from each plots, air dried for several days and prepared for chemical analysis. The nutrient contents in tuber samples were determined following the methods as suggested by Piper (1966). Nutrient uptake by tuber samples was calculated by multiplying tuber yield (t/ha) and tuber nutrient content (\%). All the data were statistically analyzed in order to get the level of significance by MSTAT-computer package program and the mean differences among treatments were compared using DMRT at 5\% level of probability (Gomez and Gomez 1984). 


\section{Results and Discussion}

Application of Kazi compost had significant positive effects on the growth parameters of potato viz. plant height, number of branches/plant, shoot length, fresh and dry weight of shoot/plant in both BAU farm as well as in farmer's field (Table 1). In BAU farm, the highest values for plant height $(48.3 \mathrm{~cm})$ and shoot length $(39.5 \mathrm{~cm})$ were observed in $\mathrm{T}_{3}(75 \%$ RFD + Kazi compost $5 \mathrm{t} / \mathrm{ha}$ ) which were statistically identical with those of $\mathrm{T}_{4}(75 \%$ RFD + Kazi compost $3 \mathrm{t} / \mathrm{ha})$ and $\mathrm{T}_{5}(75 \% \mathrm{RFD}+$ poultry manure $3 \mathrm{t} / \mathrm{ha})$ treatments. For number of branches/plant, the treatments $\mathrm{T}_{2}(100 \% \mathrm{RFD}), \mathrm{T}_{3}, \mathrm{~T}_{4}$ and $\mathrm{T}_{5}$ were statistically identical although the highest value (7.0) was noted in $T_{4}$. For both fresh and dry weight of shoot, the maximum values (81.6 and 28.0 $\mathrm{g}$, respectively) were observed in $\mathrm{T}_{3}$ and all the treatments were statistically similar except control. The growth parameters of potato grown in farmer's field showed more or less similar trend with those in BAU farm (Table 1). The tallest plant of $44.4 \mathrm{~cm}$ was found in $\mathrm{T}_{3}$ treatment which was statistically identical with those of $\mathrm{T}_{4}$ and $\mathrm{T}_{5}$ treatments. Similarly, the highest number of branches (6.9) was recorded at $T_{3}$ that was not statistically different from those observed in $T_{2}, T_{4}$ and $T_{5}$. The maximum values for shoot length $(37.7 \mathrm{~cm})$, fresh weight of shoot/plant $(75.5 \mathrm{~g})$ and dry weight of shoot/plant $(25.4 \mathrm{~g})$ were also obtained in treatment $\mathrm{T}_{3}$ where $5 \mathrm{t} / \mathrm{ha}$ Kazi compost was applied with $75 \%$ RFD of chemical fertilizers. The treatments except control were statistically identical for fresh and dry weight of shoot. In both of the locations, the control treatment showed the minimum values for all the growth parameters.

Table 1. Effect of various organic manures on growth components of potato

\begin{tabular}{|c|c|c|c|c|c|c|c|c|c|c|}
\hline \multirow[t]{2}{*}{ Treatments } & \multicolumn{5}{|c|}{ BAU Farm } & \multicolumn{5}{|c|}{ Farmer's field } \\
\hline & $\begin{array}{l}\text { Plant } \\
\text { height } \\
(\mathrm{cm})\end{array}$ & $\begin{array}{c}\text { No. of } \\
\text { branches } \\
\text { /plant }\end{array}$ & $\begin{array}{l}\text { Shoot } \\
\text { length } \\
(\mathrm{cm})\end{array}$ & $\begin{array}{c}\text { Fresh } \\
\text { weight of } \\
\text { shoot }(\mathrm{g})\end{array}$ & \begin{tabular}{l}
\multicolumn{1}{c}{ Dry } \\
weight of \\
shoot $(\mathrm{g})$
\end{tabular} & $\begin{array}{l}\text { Plant } \\
\text { height } \\
(\mathrm{cm})\end{array}$ & $\begin{array}{c}\text { No. of } \\
\text { branches/ } \\
\text { plant }\end{array}$ & $\begin{array}{l}\text { Shoot } \\
\text { length } \\
(\mathrm{cm})\end{array}$ & $\begin{array}{c}\text { Fresh } \\
\text { weight of } \\
\text { shoot }(\mathrm{g})\end{array}$ & $\begin{array}{l}\text { Dry weight } \\
\text { of shoot }(\mathrm{g})\end{array}$ \\
\hline $\mathrm{T}_{0}$ & $25.7 \mathrm{c}$ & $3.7 \mathrm{c}$ & $19.8 \mathrm{~d}$ & $37.2 b$ & $10.2 b$ & $23.5 \mathrm{c}$ & $3.2 \mathrm{c}$ & $17.4 \mathrm{~d}$ & $33.5 b$ & $9.7 b$ \\
\hline $\mathrm{T}_{1}$ & $38.7 \mathrm{~b}$ & $4.8 \mathrm{bc}$ & $29.3 \mathrm{c}$ & $72.2 \mathrm{a}$ & $26.4 \mathrm{a}$ & $31.9 \mathrm{~b}$ & $4.9 \mathrm{~b}$ & $25.5 b c$ & $64.0 \mathrm{a}$ & $20.7 \mathrm{a}$ \\
\hline $\mathrm{T}_{2}$ & $36.7 b$ & $6.3 \mathrm{ab}$ & $31.3 \mathrm{bc}$ & $76.0 \mathrm{a}$ & $24.0 \mathrm{a}$ & $38.5 \mathrm{ab}$ & $6.0 \mathrm{ab}$ & $31.9 \mathrm{c}$ & $70.1 \mathrm{a}$ & $23.4 \mathrm{a}$ \\
\hline $\mathrm{T}_{3}$ & $48.3 \mathrm{a}$ & $6.7 \mathrm{ab}$ & $39.5 \mathrm{a}$ & $81.6 \mathrm{a}$ & $28.0 \mathrm{a}$ & $44.4 \mathrm{a}$ & $6.9 \mathrm{a}$ & $37.7 \mathrm{a}$ & $75.5 \mathrm{a}$ & $25.4 \mathrm{a}$ \\
\hline $\mathrm{T}_{4}$ & $45.3 \mathrm{a}$ & $7.0 \mathrm{a}$ & $36.8 \mathrm{ab}$ & $77.4 \mathrm{a}$ & $26.2 \mathrm{a}$ & $42.7 \mathrm{a}$ & $6.8 \mathrm{a}$ & $36.9 \mathrm{a}$ & $75.2 \mathrm{a}$ & $24.2 \mathrm{a}$ \\
\hline $\mathrm{T}_{5}$ & $45.0 \mathrm{a}$ & $6.3 \mathrm{ab}$ & $36.0 \mathrm{ab}$ & $78.4 \mathrm{a}$ & $25.8 \mathrm{a}$ & $43.2 \mathrm{a}$ & $5.9 \mathrm{ab}$ & $34.6 \mathrm{ab}$ & $72.3 \mathrm{a}$ & $22.3 \mathrm{a}$ \\
\hline $\mathrm{T}_{6}$ & $36.7 \mathrm{~b}$ & $5.5 \mathrm{~b}$ & $28.7 \mathrm{c}$ & $71.4 \mathrm{a}$ & $22.6 \mathrm{a}$ & $32.5 b$ & $5.2 b$ & $25.4 \mathrm{c}$ & $67.4 \mathrm{a}$ & $20.6 \mathrm{a}$ \\
\hline $\mathrm{CV}(\%)$ & 8.61 & 16.6 & 10.9 & 22.3 & 25.5 & 7.0 & 12.4 & 9.0 & 25.1 & 20.8 \\
\hline $\mathrm{SE}( \pm)$ & 2.8 & 0.8 & 2.8 & 0.9 & 0.2 & 2.1 & 0.7 & 1.7 & 0.7 & 0.2 \\
\hline
\end{tabular}

Figures in a column having common letter(s) do not differ significantly at $\mathrm{p}=0.05$.

Yield components of potato including length, diameter and weight of tuber as well as tuber yield were significantly affected by different treatments while the number of tubers/plant was not affected (Table 2). In BAU farm, although the highest number of tuber/plant (10.7) was produced in treatment $\mathrm{T}_{4}(75 \% \mathrm{RFD}+$ Kazi compost $3 \mathrm{t} / \mathrm{ha})$, the widest tuber of $4.0 \mathrm{~cm}$ was recorded in treatment $\mathrm{T}_{3}(75 \%$ RFD + Kazi compost $5 \mathrm{t} / \mathrm{ha})$ that was statistically similar with those of treatments $\mathrm{T}_{2}\left(100 \%\right.$ RFD), $\mathrm{T}_{4}$ and $\mathrm{T}_{5}(75 \% \mathrm{RFD}+$ Poultry manure $3 \mathrm{t} / \mathrm{ha})$. In the same manner, the treatment $\mathrm{T}_{3}$ produced the longest tuber of $5.8 \mathrm{~cm}$ which was not statistically dissimilar with all other treatments except control. Interestingly, treatments $T_{3}, T_{4}$ and $T_{5}$ were statistically identical in producing the higher weight of tuber and yield maximization of potato and notably the highest 
weight of tuber/plant $(763.3 \mathrm{~g})$ and yield $(38.6 \mathrm{t} / \mathrm{ha})$ were found in $\mathrm{T}_{3}$. The lowest values for number of tuber/plant $(5.7)$, tuber diameter $(2.3 \mathrm{~cm})$, tuber length $(3.2 \mathrm{~cm})$, tuber weight/plant $(122.3 \mathrm{~g})$ and tuber yield $(7.8 \mathrm{t} / \mathrm{ha})$ were observed in control treatment.

Similar results were found in the yield and yield contributing characters of potato cultivated in farmer's field (Table 2). The maximum number of tuber/plant (10.4) was produced in treatment $\mathrm{T}_{5}$ (75\% RFD + Poultry manure 3 t/ha). Application of Kazi compost @ 5 t/ha with 75\% RFD performed the best among all the treatments as it produced the widest, longest and heaviest tuber (3.9, $5.7 \mathrm{~cm}$ and $736.5 \mathrm{~g}$, respectively) and highest tuber yield ( $32.3 \mathrm{t} / \mathrm{ha})$. Furthermore, treatment $T_{3}$ was statistically similar with $T_{2}, T_{4}$ and $T_{5}$ for tuber diameter but with $T_{1}, T_{2}, T_{4}$ and $T_{5}$ for tuber length. Similar with the results of BAU farm, treatments $T_{3}, T_{4}$ and $T_{5}$ were statistically identical in case of tuber weight and tuber yield of potato. The performance of control treatment for yield and yield parameters of potato was inferior to all other treatments as it produced the lowest values for number of tuber/plant (5.9), tuber diameter $(2.6 \mathrm{~cm})$, tuber length $(3.1 \mathrm{~cm})$, tuber weight/plant (109.2 g) and tuber yield (6.9 t/ha). In both of the locations, the different treatments may be ranked in the order of $T_{3}>T_{4}>T_{5}>T_{2}>T_{6}>T_{1}>T_{0}$ for tuber yield of potato. Again, the percent increase in tuber yield over control varied from 62.8 to 394.9 in BAU farm but 121.7 to 368.1 in farmer's field. Results of the study showed that tuber yield of potato was increased in treatments $\mathrm{T}_{1}$ up to $\mathrm{T}_{6}$, by $62.8,246.2,394.9,369.2,308.9$ and $162.8 \%$, respectively in BAU farm but by $121.7,311.6,368.1,347.8,321.7$ and $240.6 \%$, respectively in farmer's field relative to control. In both of the locations, treatment $\mathrm{T}_{3}$ gave the highest tuber yield increase over control while $\mathrm{T}_{1}$ showed the lowest yield increase.

Table 2. Effect of various organic manures on yield parameters and yield of potato

\begin{tabular}{|c|c|c|c|c|c|c|c|c|c|c|c|c|}
\hline \multirow[b]{2}{*}{$\begin{array}{l}\text { Treat- } \\
\text { ments }\end{array}$} & \multicolumn{6}{|c|}{ BAU farm } & \multicolumn{6}{|c|}{ Farmer's field } \\
\hline & $\begin{array}{c}\text { No. of } \\
\text { tuber/ } \\
\text { plant }\end{array}$ & $\begin{array}{c}\text { Tuber } \\
\text { diam. } \\
(\mathrm{cm})\end{array}$ & $\begin{array}{l}\text { Tuber } \\
\text { length } \\
(\mathrm{cm})\end{array}$ & $\begin{array}{c}\text { Tuber } \\
\text { weight } \\
\text { /plant } \\
\text { (g) }\end{array}$ & $\begin{array}{l}\text { Tuber } \\
\text { yield } \\
\text { (t/ha) }\end{array}$ & $\begin{array}{c}\% \text { Yield } \\
\text { increase } \\
\text { over } \\
\text { control }\end{array}$ & $\begin{array}{l}\text { No. } \\
\text { of } \\
\text { tuber/ } \\
\text { plant }\end{array}$ & $\begin{array}{l}\text { Tuber } \\
\text { diam. } \\
(\mathrm{cm})\end{array}$ & $\begin{array}{c}\text { Tuber } \\
\text { length } \\
(\mathrm{cm})\end{array}$ & $\begin{array}{l}\text { Tuber } \\
\text { weight/ } \\
\text { plant }(g)\end{array}$ & $\begin{array}{l}\text { Tuber } \\
\text { yield } \\
(\mathrm{t} / \mathrm{ha})\end{array}$ & $\begin{array}{c}\% \text { Yield } \\
\text { increase } \\
\text { over } \\
\text { control }\end{array}$ \\
\hline $\mathrm{T}_{0}$ & 5.7 & $2.3 \mathrm{c}$ & $3.2 \mathrm{~b}$ & $122.3 \mathrm{e}$ & $7.8 \mathrm{e}$ & - & 5.9 & $2.6 \mathrm{c}$ & $3.1 \mathrm{~b}$ & $109.2 \mathrm{e}$ & $6.9 \mathrm{~d}$ & - \\
\hline $\mathrm{T}_{1}$ & 8.0 & $3.0 \mathrm{~b}$ & $4.5 \mathrm{ab}$ & $195.0 \mathrm{~d}$ & $12.7 \mathrm{~d}$ & 62.8 & 8.6 & $3.0 \mathrm{bc}$ & $4.8 \mathrm{ab}$ & 207.6d & $15.3 \mathrm{c}$ & 121.7 \\
\hline $\mathrm{T}_{2}$ & 9.0 & $3.7 \mathrm{ab}$ & $5.2 \mathrm{a}$ & $446.7 b$ & $27.0 \mathrm{~b}$ & 246.2 & 8.9 & $3.8 \mathrm{ab}$ & $5.3 \mathrm{a}$ & $458.4 \mathrm{~b}$ & $28.4 \mathrm{ab}$ & 311.6 \\
\hline $\mathrm{T}_{3}$ & 10.3 & $4.0 \mathrm{a}$ & $5.8 \mathrm{a}$ & $763.3 \mathrm{a}$ & $38.6 \mathrm{a}$ & 394.9 & 10.3 & $3.9 \mathrm{a}$ & $5.7 \mathrm{a}$ & $736.5 \mathrm{a}$ & $32.3 \mathrm{a}$ & 368.1 \\
\hline $\mathrm{T}_{4}$ & 10.7 & $3.7 \mathrm{ab}$ & $5.7 \mathrm{a}$ & $756.2 \mathrm{a}$ & $36.6 \mathrm{a}$ & 369.2 & 10.0 & $3.8 \mathrm{ab}$ & $5.6 \mathrm{a}$ & $720.9 \mathrm{a}$ & $30.9 a$ & 347.8 \\
\hline $\mathrm{T}_{5}$ & 9.7 & $3.5 \mathrm{ab}$ & $5.3 \mathrm{a}$ & $736.7 \mathrm{a}$ & $31.9 \mathrm{ab}$ & 308.9 & 10.4 & $3.7 \mathrm{ab}$ & $5.5 \mathrm{a}$ & $718.8 \mathrm{a}$ & $29.1 \mathrm{a}$ & 321.7 \\
\hline $\mathrm{T}_{6}$ & 6.3 & $3.2 b$ & $5.0 \mathrm{a}$ & $380.0 \mathrm{c}$ & $20.5 \mathrm{c}$ & 162.8 & 7.9 & $3.2 b$ & $4.9 \mathrm{ab}$ & $397.4 \mathrm{c}$ & $23.5 b$ & 240.6 \\
\hline $\mathrm{CV}(\%)$ & 34.2 & 8.9 & 16.9 & 8.2 & 7.4 & - & 23.2 & 7.3 & 11.5 & 7.9 & 7.4 & - \\
\hline $\mathrm{SE}( \pm)$ & 2.4 & 0.2 & 0.7 & 2.3 & 1.7 & - & 1.9 & 0.4 & 0.9 & 2.6 & 1.7 & - \\
\hline
\end{tabular}

Figures in a column having common letter(s) or without letters do not differ significantly at $\mathrm{p}=0.05$.

Growth and yield enhancement of potato crop such as increased plant height, number of branches, number of tuber, weight and yield of tuber etc. from combined manure and fertilizer application were also reported by many researchers (Jaipaul et al. 2011, Venkatasalam et al. 2012, Balemi 2012, Amara and Mourad 2013, El-Sayed et al. 2014, Ahmadiet al. 2014, Shaheen et al. 2014, Suh et al. 2015, Masrie et al. 2015, Hafez et al. 2017, Koireng et al. 2018, Bekele et al. 2018, Ahmed et al. 2019). The results of the present experiments are either fully or partially 
accorded to the above mentioned comparable studies. It is clearly showed that application of $5 \mathrm{t} / \mathrm{ha}$ Kazi compost with chemical fertilizers was the best treatment as it produced the maximum values for all the growth and yield parameters of potato. Notably, Kazi compost was prepared from poultry manure and processed by adding rice straw or saw dust to maintain proper moisture. The significant increase in yield parameters and tuber yield of potato might be due to improved growth and development of potato deriving nutrients from both organic and inorganic sources. Better performance of poultry manure might be due to its higher nutrient composition and capacity to increase availability of native soil nutrient through higher biological activity (Pengthamkeeratia $e t$ al. 2011).

The uptake of nutrients by potato tuber varied significantly due to addition of Kazi compost with inorganic fertilizers (Table 3). The uptakes of N, P, K and S by potato tuber varied from 0.9 to $5.0,4.9$ to $53.7,12.4$ to 140.6 and 1.5 to $37.9 \mathrm{~kg} / \mathrm{ha}$, respectively in BAU farm but from 0.7 to 5.2, 3.6 to $41.6,13.0$ to 120.4 and 1.3 to $27.8 \mathrm{~kg} / \mathrm{ha}$, respectively, in farmer's field. For both of the locations, the maximum values for all the nutrient uptakes were found in $\mathrm{T}_{3}(75 \% \mathrm{RFD}+$ Kazi compost $5 \mathrm{t} / \mathrm{ha}$ ) while the minimum values were observed in control. For both of the locations, the different treatments may be ranked in the order of $T_{3}>T_{4}>T_{5}>T_{2}>T_{6}>T_{1}>T_{0}$ for nutrient uptake by potato tuber. Increased uptake of nutrients such as $\mathrm{N}, \mathrm{P}$ and $\mathrm{K}$ by potato plant was suggested by Masrie et al. (2015) and Islam et al. (2013) with combined use of cattle manure or poultry manure and chemical fertilizers.

Table 3. Effect of various organic manures on nutrient uptake by potato tuber

\begin{tabular}{|c|c|c|c|c|c|c|c|c|}
\hline \multirow{2}{*}{ Treatments } & \multicolumn{4}{|c|}{ Nutrient uptake $(\mathrm{kg} / \mathrm{ha})$ at BAU farm } & \multicolumn{4}{|c|}{ Nutrient uptake $(\mathrm{kg} / \mathrm{ha})$ at Farmer's field } \\
\hline & $\mathrm{N}$ & $\mathrm{P}$ & $\mathrm{K}$ & $S$ & $\mathrm{~N}$ & $\mathrm{P}$ & $\mathrm{K}$ & $\mathrm{S}$ \\
\hline $\mathrm{T}_{0}$ & $0.9 \mathrm{~d}$ & $4.9 \mathrm{f}$ & $12.4 \mathrm{e}$ & $1.5 \mathrm{~d}$ & $0.7 \mathrm{e}$ & $3.6 \mathrm{f}$ & $13.0 \mathrm{e}$ & $1.3 \mathrm{~d}$ \\
\hline $\mathrm{T}_{1}$ & $1.4 \mathrm{~cd}$ & $9.1 \mathrm{e}$ & $31.2 \mathrm{de}$ & $1.8 \mathrm{~d}$ & $1.8 \mathrm{~d}$ & $8.4 \mathrm{e}$ & $39.1 \mathrm{~d}$ & $4.9 \mathrm{~cd}$ \\
\hline $\mathrm{T}_{2}$ & $3.2 \mathrm{~b}$ & $14.1 \mathrm{~d}$ & $72.2 \mathrm{c}$ & $12.2 \mathrm{bc}$ & $3.7 \mathrm{bc}$ & $19.3 \mathrm{~d}$ & $73.3 \mathrm{c}$ & $21.3 b$ \\
\hline $\mathrm{T}_{3}$ & $5.0 \mathrm{a}$ & $53.7 \mathrm{a}$ & $140.6 \mathrm{a}$ & $37.9 \mathrm{a}$ & $5.2 \mathrm{a}$ & $41.6 \mathrm{a}$ & $120.4 \mathrm{a}$ & $27.8 \mathrm{a}$ \\
\hline $\mathrm{T}_{4}$ & $4.4 \mathrm{a}$ & $43.5 b$ & $112.3 b$ & $30.4 \mathrm{ab}$ & $4.3 \mathrm{~b}$ & $36.2 b$ & $105.4 \mathrm{~b}$ & $22.6 b$ \\
\hline $\mathrm{T}_{5}$ & $4.2 \mathrm{ab}$ & $40.6 \mathrm{~b}$ & $107.8 \mathrm{~b}$ & $17.3 \mathrm{~b}$ & $4.1 \mathrm{~b}$ & $35.2 \mathrm{~b}$ & $101.3 \mathrm{~b}$ & $19.8 \mathrm{bc}$ \\
\hline $\mathrm{T}_{6}$ & $2.7 \mathrm{bc}$ & $21.1 \mathrm{c}$ & $56.9 \mathrm{~d}$ & $4.1 \mathrm{~cd}$ & $2.8 \mathrm{c}$ & $25.1 \mathrm{c}$ & $74.9 \mathrm{c}$ & $5.4 \mathrm{c}$ \\
\hline $\mathrm{CV}(\%)$ & 24.6 & 7.9 & 20.4 & 10.0 & 21.9 & 9.2 & 16.8 & 8.4 \\
\hline $\mathrm{SE}( \pm)$ & 0.7 & 1.7 & 14.1 & 1.4 & 0.9 & 2.3 & 11.9 & 1.4 \\
\hline
\end{tabular}

Figures in a column having common letter(s) do not differ significantly at $\mathrm{p}=0.05$.

The contradiction between the results of the two sites may be attributed to the variation in soil type and moisture conditions at application time of manures as well as the type and amount of organic manures used with chemical fertilizers. Thus, the overall results confirmed that organic manures namely Kazi compost can effectively enhance the growth and yield attributes and tuber yield of potato with satisfactory improvement in tuber quality. The effects of two doses of Kazi compost (5 and $3 \mathrm{t} / \mathrm{ha}$ ) were similar and each of them could lessen the application of inorganic fertilizers by $25 \%$. Followed by Kazi compost, the performance of poultry manure was better among the organic manures. Thus, considering the high cost of inorganic fertilizers and their negative effects on the environment, reduced usage at three-fourth of the recommended rates combined with 3 ton Kazi compost is feasible option friendly to the farmers, soil and environment. However, further comparative studies under different agro-climatic conditions with other vegetable crops are required before drawing a final conclusion. 


\section{Acknowledgements}

The authors gratefully acknowledge KAZI FARMS GROUP for financial support and the Department of Soil Science, BAU for providing research facilities to conduct this research work.

\section{References}

Ahamadi S, Dagar JC and Mani D 2014. Impact of FYM and potassium interactions on potato yield cultivated on moderate saline soils. J. Soil Salinity Water Quality 6(1):59-63.

Ahmed F, Mondal MMA and Akter MB 2019. Organic fertilizers effect on potato (Solanum tuberosum L.) tuber production in sandy loam soil.Int. J. Plant Soil Sci. 29(3):1-11.

Amara DG and Mourad SM 2013.Influence of organic manure on the vegetative growth and tuber production of potato (Solanum tuberosum L. varspunta) in a Sahara desert region Intl. J. Agri. Crop Sci. 5:27242731.

Balemi T 2012. Effect of integrated use of cattle manure and inorganic fertilizers on tuber yield of potato in Ethiopia. J. Soil Sci. Plant Nutr. 12(2):257-265.

Bekele BG, Belew D and Abebe T 2018. NPSZnB fertilizer and cattle manure effect on potato (Solanum tuberosum L.) yield and yield components in Awi Zone, Ethiopia. Int. J. Soil Sci.13:35-41.

Devaux A, Kromann P and Ortiz O 2014. Potatoes for sustainable global food security. Potato Res. 57:185199.

El-Sayed SF, Hassan HA, El-Mogy MM and Abdel-Wahab A 2014. Growth, yield and nutrient concentration of potato plants grown under organic and conventional fertilizer systems. Am. Eurasian J. Agric. Environ. Sci. 14(7):636-643.

FRG (Fertilizer Recommendation Guide) 2018. Fertilizer Recommendation Guide-2018. Bangladesh Agricultural Research Council, Farmgate, Dhaka, p. 161.

Gomez KA and Gomez AA 1984. Statistical Procedures for Agricultural Research. John Wiley and Sons, New York, p. 680.

Hafez OM, Abuol-Nasr MH, Dalia MT, Nassef DMT and Gameh MA 2017. Effect of organo-mineral fertilization on vegetative growth and productivity of potato under the new valley conditions. J. Plant Produc. Mansoura Univ. 8(6): 685-691.

Hale AL, Reddivari L, Nzaramba MN, Bamberg JB and Miller JCJr 2008. Interspecific variability for antioxidant activity and phenolic content among Solanum species. Amer. J. Potato Res .85(5):332-341.

Hussain T 2016. Potatoes: ensuring food for the future. Adv. Plants Agric. Res. 3(6):178-182.

Islam MM, Akhter S, Majid NM, Ferdous J and Alam MS 2013. Integrated nutrient management for potato (Solanum tuberosum) in grey terrace soil (Aric Albaquipt). Aust. J. Crop Sci. 7(9):1235-1241.

Jaipaul, Sharma S and Sharma AK 2011. Effect of organic fertilizers on growth, yield and quality of potato under rainfed conditions of central Himalayan region of Uttarakhand. Potato J. 38(2):176-182.

Kandil AA, Attia AN, Badawi MA, Sharief AE and Abido WAH 2011. Effect of water stress and fertilization with inorganic nitrogen and organic chicken manure on yield and yield components of potato. Aust. J. Basic Appl. Sci. 5(9):997-1005.

KoirengRJ, Singh LN and Devi KP 2018. Integration of different sources of organic manure and micronutrients on growth, yield and quality of potato (Solanum tuberosum L.) grown under new alluvial soil condition. Indian J. Agr. Res. 52(2):172-176.

Masrie BZ, Dechassa N, Tana T, Alemayehu Y and Abebie B 2015. The effects of combined application of cattle manure and NP fertilizers on yield and nutrient uptake of potato in North-Eastern Ethiopia. J. Sci. Sustain. Dev. 3(1):1-23.

Pengthamkeeratia P, Motavallib PP and Kremerc RJ 2011. Soil microbial activity and functional diversity changed by compaction, poultry litter and cropping in a clay pan soil. Appl. Soil Ecol. 48:71-80.

Piper CS 1966. Soil and Plant Analysis: a laboratory manual of methods for the examination of soils and the determination of the inorganic constituents of plants. Hans Publishers, Bombay, p 368. 
Sanwen Huang N, Robin Buell C and Richard Visser GF 2011. Genome sequence and analysis of the tuber crop potato. Nature 475:189-195.

Shaheen AM, Rizk FA and Abd El-Rahman NG 2014. Growth, tubers yield and its nuritional value of potatoes as affected by cattle, chicken and/or chemical nitrogen fertilizer. Middle East J. Agric. Res. 3(2):292-301.

Siddique MNA, Sultana J, Huda MS, Abdullah MR and Chowdury MA 2015. Potato production and management with preference to seed potato supply chain, certification and actors involve in Bangladesh. Int. J. Bus. Manag. Soc. Res. 1(1):1-13.

Suh C, Meka SS, Ngome AF, Neba DA, Kemngwa IT, Sonkouat AD and Njualem D 2015. Effects of organic and inorganic fertilizers on growth and yield of potato (Solanum tuberosum L.) in the western highlands of Cameroon. Int. J. Dev. Res. 5(2):1-5.

SYB (Statistical Yearbook Bangladesh) 2018. 38 ${ }^{\text {th }}$ edition. Bangladesh Bureau of Statistics. Statistics and Informatics Division, Ministry of Planning, Govt. People's Republic of Bangladesh, p 599.

Timsina J 2018. Can organically sources of nutrients increase crop yields to meet global food demand? Agronomy 8:214.

Venkatasalam EP, Singh SS and Sharma S 2012. Effect of organic manures on yield and yield attributing characters of potato. Potato J. 39(1):84-87.

(Manuscript received on 5 June, 2020; revised on 29 March, 2021) 